\title{
Capitalism, Development, and Democracy
}

\author{
Capitalismo, desenvolvimento e democracia
}

ADAM PRZEWORSKI*

RESUMO: O capitalismo é uma condição necessária, mas não suficiente, para a democracia. Essa relação é historicamente contingente. É verdade que a democracia tende a prevalecer nos países capitalistas mais desenvolvidos. Mas isso não é porque o desenvolvimento capitalista gera a democracia. A razão é que, uma vez que a democracia esteja presente nas sociedades ricas, todo mundo tem muito em jogo para arriscar uma luta pela ditadura. PALAVRAS-CHAVE: Capitalismo; democracia; condições históricas; desenvolvimento econômico

ABSTRACT: Capitalism is a necessary but not a sufficient condition for democracy. This relation is historically contingent. It is true that democracy tends to prevail in the most developed capitalist countries. But this is not because capitalist development breeds democracy. The reason is that once democracy is present in wealthy societies, everyone has too much at stake to risk a struggle for dictatorship.

KEYWORDS: Capitalism; democracy; historical conditions; economic development. JEL Classification: O1; P1; P16.

\section{INTRODUCTION}

One persistent feature of Bresser-Pereira's thought is that he never loses the sight of the central issues, even when analyzing concrete historical events. In his paper on "Why democracy became the preferred regime only in the twentieth century?", Bresser argues that democracy arose historically only when and in those countries which consolidated capitalism. Moreover, he sees this development as historically necessary and as rational, both for capitalists and for workers.

The problem with this analysis is that it offers only necessary but not sufficient conditions. As such, while it offers a suggestive explanation, it has little predictive power. By claiming both historical necessity and collective rationality, Bresser

\footnotetext{
* New York University, New York/NY, EUA. E-mail: adam.przeworski@nyu.edu. Submitted: April 2004; accepted: May 2004.
} 
makes this relation inevitable. Yet examining the historical record shows it to be much more contingent. While capitalism makes democracy possible, it does not render it necessary. Just observe that an enduring democracy emerged in India in 1947 , when that country had per capita income of $\$ 556,{ }^{1}$ while dictatorship survived in Singapore when the income of this country was $\$ 18,300$. The levels of development under which democracy emerged in particular countries varied greatly and in several countries the advance of democracy suffered lengthy reversals in spite of continued capitalist development. Dictatorship is as compatible with capitalism as is democracy. Hence, the relation between capitalism development and democracy requires an analysis of concrete historical contingencies. It cannot be deduced from first principles. History has no logic, only patterned contingencies, and the role of historical analysis is to identify these patterns.

To clarify the issues entailed, it is best to begin with Marx. While Bresser's analysis of capitalism follows that of Marx in volume III of The Capital, he ignores Marx's political analysis of the French events between 1848 and 1851, and it is there that Marx spells out his views of the relation between capitalism and democracy. Now, as I argued a long time ago (Przeworski 1986), Marx was wrong when he claimed that democracy and capitalism cannot coexist. But he did offer a framework for the analysis of contingencies entailed in this relation. These theoretical issues are the subject of the section that follows.

In the next section, I examine historical evidence covering the period between 1946 and 1999 . The analysis begins with the well-known observation by Lipset (1960) that most developed countries have democratic regimes while most poor countries suffer from dictatorship. Yet, as was first shown by Przeworski and Limongi (1997), this pattern emerges not because democracies are more likely to be established when countries become more developed but because, if they are established for whatever reasons, they are more likely to last in developed countries.

Finally, in the last section, I provide an interpretation of this patterns and return to the relation between capitalism and democracy. This interpretation is based on a model, which is briefly outlined in the Appendix.

\section{CAPITALISM AND DEMOCRACY}

Capitalism liberated direct producers from the political authority of owners of the means of production. As distinct from feudalism and various forms of slavery from which it emerged, under capitalism the owners of the means of production are not legal superiors of those whom they employ. As Marx observed some-

\footnotetext{
${ }^{1}$ All income figures are in 1985 purchasing power parity international dollars.
} 
where (I am citing from memory), "that medieaval proverb 'nulle terre sans seigneur' was replaced by that other proverb 'l'argent n'a pas de maître'."

In Marx's view, this separation of property from authority is necessary for capitalism to exist. To be able to move to firms which expand their stock of capital, investing in new technologies and new processes, workers must be mobile. To keep wages low, workers must compete in the labor market. Hence, workers must be free from political authority of their employers. Otherwise, capitalists could not invest and compete with one another, and competition is the engine of capitalism development.

Bresser takes this observation to be the "new historical fact" that made democracy possible: "When the capitalist revolution is completed we have a market economy: profits and wages start to be regularly in the market. Since that moment the state ceases to be crucial to wealth acquisition and disposal. It remains relevant, but not any more a condition for the economic elite's existence. Thus, the new capitalist class can do what the previous dominant classes could not: indulge in democracy...” (p. 11; italics mine).

The problem with this reasoning is that can does not imply must, or even will. Here we must return to Marx's political analyses. Marx observed that, by liberating the immediate producers from the political authority of owners of the means of production, capitalism produced a new historical force, namely, the working class. But the working class would constitute a threat to capitalism. As long as the emergent capitalist class had only one enemy, the feudal landowners whose political control it sought to abolish, the bourgeoisie needed to struggle under the slogan of liberty, against legal restrictions on property. But when the working class appeared on the historical horizon, whether it was in Waterloo in 1816, Lyon in 1830 , or the Champs de Mars in Paris in 1848 - historians disagree about it liberty became a two-edged sword, since it could be used by workers against private property. And when in France in 1848 workers for the first time used their newly acquired political rights, in the form of suffrage, to present a threat to the bourgeoisie capitalists immediately run for the cover of a military dictatorship.

Even though it is well known, Marx's reasoning merits reconstructing. He reasoned as follows: (1) To establish a social system in which surplus would be extracted from the immediate producers by means of voluntary exchange, the bourgeoisie had to abolish feudal restrictions on property and on the freedom of immediate producers. (2) Once immediate producers acquired legal and political rights, they would seek to advance their material interests by organizing against the system of private property. (3) Hence, the bourgeoisie found itself in a dilemma: to accumulate, it needed free labor but, deprived of political authority it could not control the threat to its property. (4) The choice made, at least by the French bourgeoisie in 1851, was to abdicate its political power to the military, so as to protect its economic power.

Marx thought that this historical dynamic was inevitable. Indeed, he concluded 
that the combination of democracy and capitalism, the "bourgeois republic," was impossible. It could not last. Writing in 1851 (1934: 18), he expressed the belief that capitalist democracy is "only the political form of revolution of bourgeois society and not its conservative form of life." Twenty years later he still viewed democratic form of capitalist societies as "only a spasmodic, exceptional state of things... impossible as the normal form of society" (1971: 198). This inherent instability resulted, in Marx's view, from the fact that the combination of private ownership of means of production with political democracy generates a contradiction:

The classes whose social slavery the constitution is to perpetuate, proletariat, peasantry, petty bourgeoisie, it puts in possession of political power through universal suffrage. And from the class who old social power it sanctions, the bourgeoisie, it withdraws the political guarantees of this power. It forces the political rule of the bourgeoisie into democratic conditions, which at every moment jeopardize the very foundations of bourgeois society. From the ones it demands that they should not go forward from political to social emancipation; from the others they should not go back from social to political restoration. (1952: 62).

Marx was not alone. Indeed, the belief that democracy, universal suffrage but also the freedom to form unions, must inevitably threaten the very existence of private property was almost universally shared across the ideological spectrum of the first half of the nineteenth century. Already James Madison observed that "democracies have ever been spectacles of turbulence and contention; have ever been found incompatible with personal security or the rights of property" (Federalist \#10). The Scottish philosopher James Mackintosh predicted in 1818 that if the "laborious classes" gain franchise, "a permanent animosity between opinion and property must be the consequence" (cited in Collini, Winch and Burrow, 1983: 98). David Ricardo was prepared to extend suffrage only "to that part of them [the people] which cannot be supposed to have an interest in overturning the right to property (ibidem: 107). In 1842, Thomas Macalauy (1900: 263) pictured universal suffrage as "the end of property and thus of all civilization." And modern intuitions point the same way. In the median voter model, a combination of political equality (one-persononevote) with economic inequality generates tax rates that stop short of fully equalizing incomes only because of the deadweight costs of taxation.

Yet Marx and his contemporaries were wrong. While democracy is not inevitable under capitalism, neither is it impossible. Several capitalist countries established durable democratic regimes and in many of them parties representing workers won elections and governed during extended periods without confiscating property or otherwise undermining the basis of capitalist society.

In Marx's analysis, the bourgeoisie must choose the lesser of two evils: finding some modus vivendi with the working class or becoming dependent on the military. Let me consider these two threats to the bourgeoisie in turn. 
The only dissenter to the views cited above was James Mill, who challenged his contemporaries "to produce an instance, so much as one instance, from the first page of history to the last, of the people of any country showing hostility to the general laws of property, or manifesting a desire for its subversion" (cited in Collini, Winch and Burrow 1983: 104). While such instances did eventually materialize, in many countries workers and capitalists learned to coexist within democratic framework. Working class organizations accepted the system of private property and limited their redistributive demands so as to allow capitalists to appropriate profits. This moderation stems in my view from two constraints. First, working class organizations must consider that by threatening property they may push the bourgeoisie to seek refuge under the protection of dictatorship. While this may not be a dissuasive threat in poor countries, where wages hover around subsistence and workers have little to lose, it becomes binding in developed societies, when a failed revolutionary movement carries the risk of a significant deterioration of material conditions of workers (see below). To use the classical language, the working class becomes deradicalized when it is bourgeosified. Secondly, once workers accept the existence of private property of means of production, their future consumption and employment depends on investment by capitalists, which, in turn, depends on the rate of profit and, again in turn, on wage rates and taxes. Concerned about their future material welfare, workers must restrain their demands, so as to induce capitalists to invest. ${ }^{2}$ In the end, while capitalists share with workers the fruits of development, even when workers enjoy full political and labor rights, they do not threaten capitalism in developed countries.

The second threat comes from the military. As Marx observed, when the bourgeoisie seeks refuge under the military rule, it condemns itself to political oblivion; it becomes defenseless. Nothing says that the military would rule in the interest of the bourgeoisie: they may and in many countries they did, but they may not. As Bresser (1978) and Cardoso (1986) observed almost at the same time, in the middle 1970s several sectors of the Brazilian bourgeoisie felt threatened by the statist ambition of the military and began to look at democracy much more favorably than they did in 1964. I am not arguing that the military are omnipotent: unless they decide to confiscate the property, they too depend on the investment decisions of the bourgeoisie and must trade-off their present and future consumption. $\mathrm{My}$ only point is that the military can present a threat to the bourgeoisie as much as organized workers can.

Since the bourgeoisie is caught between two evils, democracy is a contingent outcome of conflicts among several organized groups. It is neither inevitable nor impossible.

\footnotetext{
2 This argument, “class compromise," was developed in Przeworski (1986).
} 


\section{HISTORICAL PATTERNS}

Contingency is not the same as indeterminacy: it does not imply that we cannot identify the historical patterns by which capitalism and democracy coevolved. All it means that the combination of capitalism and democracy depends on the specific historical conditions of each country and each period. In what follows, I search for such conditions, using information about 199 countries that existed at any time between 1946 and 1999 .

Before we enter into theoretically motivated considerations, we must understand the mechanics of the processes that generate democracy. Bresser's association of completed capitalist revolutions with democratic regimes follows the observation of Lipset (1960) that most developed countries are democratic, while most poor countries have dictatorships of different stripes. This much is obviously true. But to understand why this is so we must ask separately why democracies emerge and why they survive once established. It may be that, as modernization theory would have it, democracies are more likely to emerge if countries are more developed. But it may also be that democracies emerge independently of the level of development but, if they emerge for some other reasons, they are more likely to survive in more developed countries. Either of these paths will generate the observed association between the density of democracy and the level of development, but the mechanisms that generate it are historically distinct and have different determinants.

It turns out that Lipset's hypothesis that "The more well-to-do a nation, the greater the chances it will sustain democracy," is true, while the thesis, also often attributed to Lipset, that "if other countries become as rich as the economically advanced nations, it is highly probable that they will become political democracies" (this is O'Donnell's 1973: 3 paraphrase) is false.

Indeed, as already Przeworski and Limongi (1997) observed, no democracy ever fell in a country wealthier than Argentina in 1976, \$6,055. This is a startling fact, given that throughout history about seventy democracies collapsed in poorer countries. In contrast, thirty-five democracies spent about 1000 years under more developed conditions and not one died. Developed democracies survived wars, riots, scandals, economic and governmental crises, hell or high water.

As Figure 1 shows, the probability that democracy survives falls steeply and monotonically in per capita income (the vertical bars are local standard errors). Between 1950 and 1999, the probability that a democracy would die during any particular year in countries with per capita income under $\$ 1000$ was 0.089 , which implies that their expected life was about eleven years. Between $\$ 1001$ and $\$ 3000$, this probability was 0.0366 , for an expected duration of about twentyseven years. 
Figure 1: Transitions to dictatorship, given per capita income

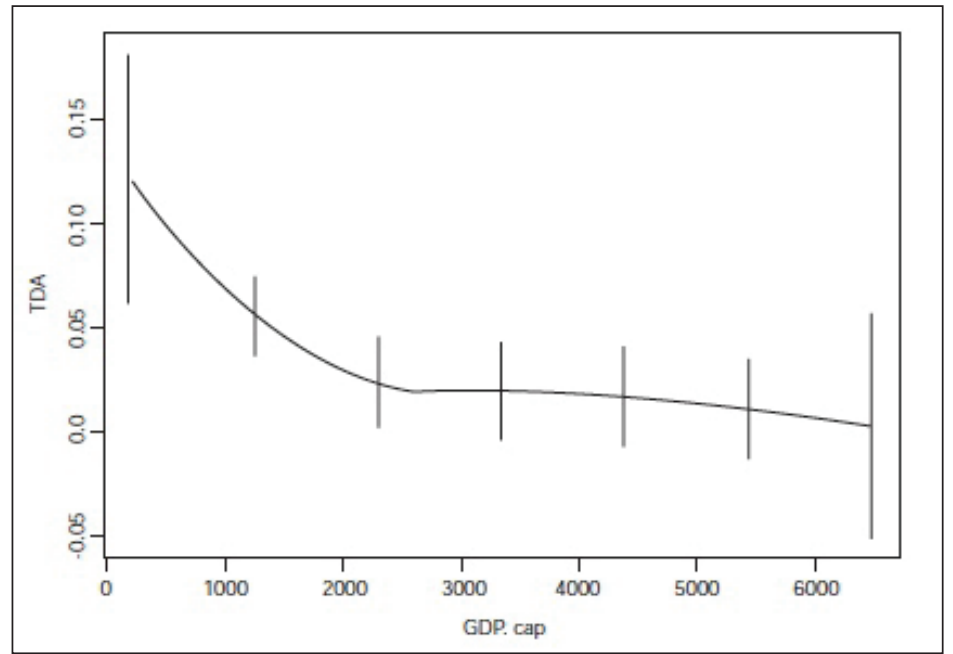

Between $\$ 3001$ and $\$ 6055$, the probability was 0.0164 , which translates into about sixty-one years of expected life. And what happens above $\$ 6055$ we already know: democracy lasts forever.

This observation is confirmed by statistical analysis, which shows that increasing per capita income greatly increases the probability of survival of democracy (see col.1 of Table 1). Moreover, note in the second column of this table that the dependence of the durability of democracy on income holds when we consider the history of political regimes of a particular country (STRA, about which below).

Table 1: Transition Probabilities as a Function of Per Capita Income (Probit Estimates)

\begin{tabular}{lcc}
\hline COLUMN & 1 & 2 \\
\hline Transition to dictatorship & 2423 & 2423 \\
N CONSTANT & $-1.31^{* * *}$ & $-1.3566^{* * *}$ \\
& $(0.12)$ & $(0.1237)$ \\
GDP/cap & $-0.2262^{* * *}$ & $-0.2672^{* * *}$ \\
& $(0.0426)$ & $(0.0516)$ \\
STRA & & $0.2280^{* * *}$ \\
& & $(0.0755)$ \\
LOGL & -198.21 & -193.98 \\
\hline Transition to democracy & & \\
\hline N & 3023 & 3023 \\
CONSTANT & $-2.08^{* * *}$ & $-2.20^{* * *}$ \\
& $(0.07)$ & $(0.08)$ \\
GDP/cap & $0.0572^{* *}$ & 0.0306 \\
STRA & $(0.0233)$ & $(0.0256)$ \\
& & $0.3375^{* * *}$ \\
LOGL & & $(0.0506)$ \\
\hline
\end{tabular}

Note: All variables are lagged one year. 
In turn, the relation between economic development and transitions to democracy is more complicated and controversial. Przeworski and Limongi claimed on the basis of data for 1950-90 that transitions to democracy occur independently of the level of development, as measured by per capita income. Przeworski, Alvarez, Cheibub, and Limongi (2000) maintained the same, although they also found indications that the probability of transition from authoritarianism to democracy first increases and then declines in per capita income. Yet these conclusions are disputed by Boix and Stokes (2002) as well as by Epstein et al. (2003).

Here is some evidence. First examine Figure 2, which shows the probability of transitions to democracy as a function of per capita income. As you see, this probability increases slightly up to a point and then declines. But since observations of wealthy dictatorships are few, the standard errors are large.

Figure 2: Transitions to democracy, given per capita income

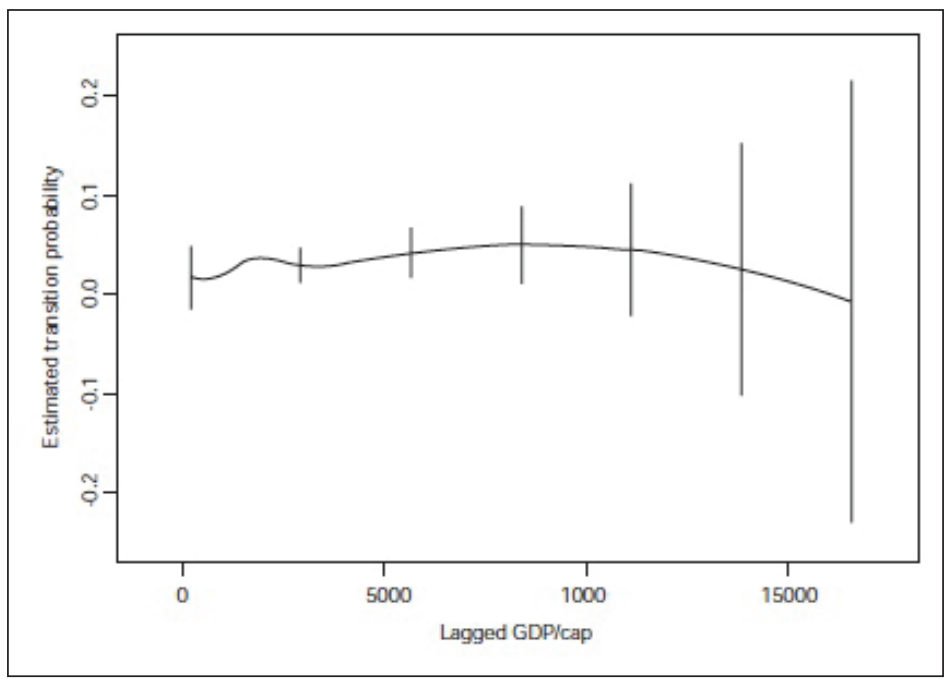

Table 1 gives more information. Note in column 1 that the coefficient of per capita income is positive and significant, even if small. But note in column 2 that this coefficient becomes indistinguishable from zero when we consider the history of regimes. STRA is a variable that counts how many completed spells of democracy (hence also transitions to dictatorship) a country experienced up to the current year. Here is a story that accounts for these patterns (for the evidence on which this story is based, see Przeworski 2003).

Dictatorships that emerge in relatively more developed countries have shorter lives. The reason is not necessarily that they are harder to consolidate when countries are more developed: it turns out that when dictatorships emerge in more developed countries they inherit a more unstable past and that past instability feeds current instability. Hence, the first part of the story is that dic- 
tatorships established at higher income levels inherit more instability, past instability makes them more vulnerable, and as a result their lives are shorter. Secondly, conditional on the initial income, development under dictatorship does not undermine the stability of these regimes. This finding flies in the face of modernization theory: if transitions to democracy are more likely at higher levels of development, then one should observe that, at least if a dictatorship emerged at a high income level, those dictatorships that increased income more should be more likely to die. If anything, just the opposite is true. Hence, even if dictatorships that are established at higher income levels are less stable, development consolidates them.

In the end, the only systematic pattern of transitions to democracy concerns a handful of dictatorships that inherited a fair dose of instability, were led by the military (except for Peru under Fujimori), and, emerged at relatively high income levels (except for Sudan). These military dictatorships came to power to thwart the threat of popular mobilization (O'Donnell 1973) and, even if each regime experienced internal tensions between those who wanted to found a permanent authoritarian order and those who wanted only to restore the pre-existing capitalist order, the latter gained an upper hand, often with the support of the respective bourgeoisies. None of these regimes generated much development and they all died at income levels well below those of some civilian dictatorships. Indeed, the highest income ever reached by a dictatorship headed by a military was $\$ 7,294$ (Spain under Franco in 1974), while six civilian dictatorships survived a total of thirty-seven years at higher incomes (several years in Singapore, Taiwan, East Germany, and the Soviet Union, plus a single year in Iraq and Malaysia). The mountain in Figure 3 consists of these high-entry-income military regimes with an unstable past, while the small ridge at lower income levels reflects Sudan. ${ }^{3}$ The rest of the surface is almost flat, even if it is divided by a ripple that goes diagonally from middle income with high instability to high income with no past instability.

Here then is the story. Let democracy be defined by two characteristics: (1) The government is not formally responsible to some nonelected power (the Crown, House of Lords until 1911, military, Council of Faith, a foreign government) and (2) The incumbent government can be defeated under the same rules under which it has been elected. This definition yields the dating of democracies found in Przeworski et al. (2000: Table 2.8) and extended to 1999 here. Suppose we were to begin in 1750, when there were no democracies by this definition. Economic historians report that at the time all countries had relatively low incomes and there was relatively little cross-country income dispersion. Some countries grew; others

\footnotetext{
${ }^{3}$ They are, in increasing income levels, Turkey (ENTRY YEAR=1980, STRA=1), Greece (1967, 2), Chile $(1973,2)$, Thailand (1991, 2), Suriname (1980, 1), Uruguay (1973, 1), and Argentina (1955, 2; 1962, 3; 1966, 4; 1976, 5).
} 


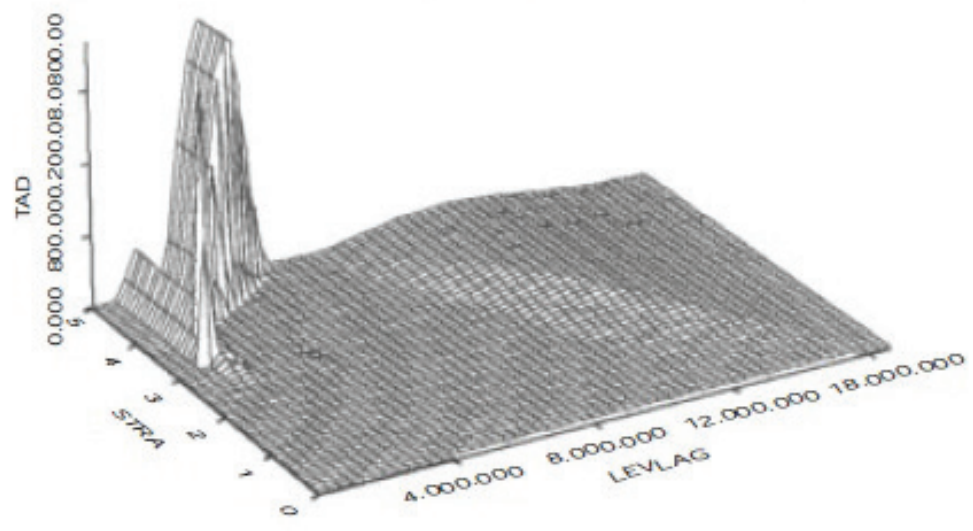

stagnated. Random events - those that we did not observe systematically at least here - generated some democracies. Where the dice had fallen on countries that already had higher income, democracy was more likely to endure. Where they had picked countries with still low incomes, democracy was likely to fall and the country would accumulate a transition. Past regime instability made both regimes less stable, so that countries became heterogeneous. Those with high past instability were taken over by the military, who did not stay long. In politically more stable countries, civilian dictatorships endured. Hence, after a long time we observed some stable dictatorships in developed countries. If they eventually died, it was because of hazards independent of income. In the meantime, new countries appeared, typically with very low incomes. Either they were born as dictatorships or democracy was likely to fall: democracy is brittle in poor countries. Some of them grew, and their pattern was the same as that of old countries. Most stagnated and they were likely to remain authoritarian.

The most important conclusion of this story is that the reason we observe the association between development and democracy is that democracy is an absorbing state in developed societies, not because countries are more likely to become democratic when they are more developed.

\section{BACK TO THEORY}

Why would it be true that transitions to democracy occur independently of development, while democracy is more stable in more developed countries? I am certain that the explanation I offer is not only plausible one but interpreting these patterns theoretically is not easy, so that alternative explanations are hard to construct. I first summarize the argument verbally and then, for mathematically inclined reader, offer rudiments of a model on which this argument is based. 
In light of Marx's analysis, the bourgeoisie faces two threats. Under democra$\mathrm{cy}$, the threat is that workers would use their right to organize to drive wages above the competitive level and that the poor, as citizens, would vote to redistribute incomes gained in the market. Under dictatorship, the threat is that the bourgeoisie could not defend itself from extraction by the dictators.

Suppose that the status quo is dictatorship. The bourgeoisie is not taxed to redistribute incomes to the poor but, in one form or another, pays rents to the military. Capitalists prefer to remain under the military tutelage if the rents they must sacrifice are lower than the costs of redistribution expected under democracy. This preference turns out to be independent of income: all that matters are shares of income capitalists lose under the two alternative states of the world. Transitions occur if for some reason capitalists believe that they would not be taxed much under democracy, which will be true if the income distribution is relatively egalitarian, or if the military becomes extortionist. But, again, they occur independently of the level of development.

Now suppose that a transition did occur and the status quo is democracy. Assume that the bourgeoisie thinks it would do better under dictatorship. But if it moves for dictatorship, it may be defeated and may end up getting lower income than under democracy. The military may or may not support it; they may be procapital but they may also be nationalist, populist, or just simply corporate. For simplicity - this is not an important assumption — assume that if the bourgeoisie is defeated, incomes from capital (but not from labor) become completely equalized, say because of public ownership of firms. Now we still need to assume - and I warn that this assumption is crucial — that if they are defeated, capitalists enjoy their income less than they would if they owned the means of production and lived on income from capital. This assumption can be rationalized by assuming that when capital assets are equally distributed, former capitalists must work for a living - a factory owner becomes an engineer in his former factory — and exerting labor generates disutility.

Under these assumptions, as per capita income increases, the stakes of the bourgeoisie in turning against democracy become larger, where by "stakes" I mean the difference between their utility under democracy and when their attempt to subvert it fails. The bourgeoisie has too much to lose in developed countries to become adventuresome. Hence, as per capita income increases, capitalists are willing to tolerate a higher degree of redistribution. And the same argument holds for workers, namely, that as per capita income increases, they are willing to tolerate a lower degree of redistribution. As a result, democracies survive in more developed countries and not in less developed ones.

I realize that this is not a simple argument and one may question the assumptions on which it is founded. To assure the reader that it is logically consistent, I outline the rudiments of the model on which it is based (for proofs see Przeworski, forthcoming, and Benhabib and Przeworski 2004) in the Appendix. But regardless 
whether this particular explanation of the observed historical patterns is or is not valid, I hope to have shown that the relation between capitalism and democracy is highly contingent. Democracy is a contingent outcome of conflicts, not a necessary consequence of capitalist development.

\section{APPENDIX: THE MODEL}

Assume that the population of unit mass is divided into three income categories: poor, middle, and rich. Per capita income is $y \geq 1$, and each of the homogeneous rich have income $\alpha_{R} y$, where $\alpha_{R}>1$, so that incomes of the rich are higher than the mean. Under democracy, the median voter, who has middle income (which need not be much higher than income of the poor) decides at which rate, $\tau$; to tax incomes. As standard in such models, tax revenue is distributed equally to everyone, so that those with incomes above the mean lose and those with incomes below gain from redistributions. Redistributing incomes is costly, and the shadow cost of public funds is $\lambda$. Hence, the post-redistribution income of the rich under democracy will be

$$
\left[(1-\tau) \alpha_{R}+\tau(1-\lambda \tau)\right] y=\left[\alpha_{R}-\tau\left(\alpha_{R}-1+\lambda \tau\right)\right] y ;
$$

where $\tau\left(\alpha_{R}-1+\lambda \tau\right)$ is the share of average income which is taken away from each rich person through the democratic mechanism. It can be shown that for any

$$
\lambda>0, \alpha_{R}-\tau\left(\alpha_{R}-1+\lambda \tau\right)>1
$$

Under dictatorship favorable to the rich, their incomes are not redistributed to the poor and the middle but some of it, a share $r$ is extorted by the military. Hence, each rich gets

$$
\left(\alpha_{R}-r\right) y
$$

For simplicity, the utility of consumption (since this is a static model, all incomes are consumed), is

$$
U(\mathrm{c})=\mu \log c,
$$

where, for the moment assume $\mu=1$.

Suppose the status quo is dictatorship. The bourgeoisie prefers to remain under dictatorship if

$$
\log \left(\alpha_{R}-r\right) y>\log \left[\alpha_{R}-\tau\left(\alpha_{R}-1+\lambda \tau\right)\right] y:
$$

As you see, income, $y$, disappears from this comparison, and when rewritten, the condition becomes

$$
r<\tau\left(\alpha_{R}-1+\lambda \tau\right)
$$


If the military are satisfied with low rents, if democracy would generate high taxes, if the distribution of income is unequal ( $\alpha_{R}$ is high), or if the deadweight losses of redistribution, $\lambda$; are high, capitalists prefer to remain under dictatorship. If the military becomes extortionist or if capitalists think they would not be taxed much, they prefer democracy. Hence, if these parameters change, a transition can occur. But income plays no role.

Now suppose that the status quo is democracy and assume that (4) holds: capitalists think they would do better if they could establish dictatorship. But if they try to provoke the military to act of their behalf, they may lose. Let the probability that the military would support the bourgeoisie be $q$ and the probability that it would turn against them $1 q$. Assume that if the coup is unsuccessful, capitalists receive income lower than they would under democracy (I assume it to be the average income, but the argument holds as long as their income would be lower than under democracy) and they suffer disutility $\mu<1$. Then they prefer to turn against democracy if

$$
\log \left[\alpha_{R}-\tau\left(\alpha_{R}-1+\lambda \tau\right)\right] y<q \log \left(\alpha_{R}-r\right) y+(1-q) \mu \log y .
$$

Rewriting this condition yields

$$
\log \left[\alpha_{R}-\tau\left(\left[\alpha_{R}-1+\lambda \tau\right)\right]-q \log \left(\alpha_{R}-r\right)<(1-q)(\mu-1) \log y .\right.
$$

Now, note that the left-hand side of this equation is constant, while the right hand side declines as income increases (because $\mu 1<0$ ). Hence, if the left-hand side of this condition is positive, which will be true if the capitalists cannot rely on the support of the military, they will never turn against democracy. If $q$ is sufficiently high, specifically, $q>\log \left[\alpha_{R}-\tau\left(a_{R}-1+\lambda \tau\right)\right] / \log \left(\alpha_{R}-r\right)$, the left-hand side is negative, and the bourgeoisie turns against democracy when income is low but not when it is high.

\section{REFERENCES}

BENHABIB, Jess, and Adam PRZEWORSKI (2004). "The Political Economy of Redistribution under Democracy.” Ms. Department of Economics and Department of Politics. New York University. BOIX, Carles, and Susan STOKES (2002). "Endogenous Democratization.” Ms. Department of Political Science, University of Chicago.

BRESSER-PEREIRA, Luiz Carlos (1978). O Colapso de uma Aliança de Classes. São Paulo: Editora Brasiliense.

BRESSER-PEREIRA, Luiz Carlos (2002). "Why democracy became the preferred regime only in the twentieth century?". Presented at the III Conference of the Brazilian Society of Political Science, ABCP, Niteroi, July 29-31.

CARDOSO, Fernando Henrique (1986). "Entrepreneurs in the Transition Process: The Brazilian Case". In O'Donnell, Schmitter e Whitehead (orgs.), Transitions from Authoritarian Rule: Latin America. Baltimore: The John Hopkins University Press.

COLLINI, Stefan, Donald WINCH and John BURROW (1983). That Noble Science of Politics. Cambridge: Cambridge University Press. 
EPSTEIN, David L., Robert BATES, Jack GOLDSTONE, Ida KRISTENSEN, and Sharyn O'HALLORAN (2003). "Democratic Transitions". Paper prepared for presentation at the Annual Meeting of the Midwest Political Science Association, Chicago, April 3-6.

LIPSET, Seymour M. (1960). Political Man. Garden City, New York, Doubleday.

MACAULAY, Thomas B. (1900). Complete Writings, vol. 17. Boston and New York: Houghton-Miin.

MARX, Karl (1934). The Eighteenth Brumaire of Louis Bonaparte. Moscow: Progress Publishers.

MARX, Karl (1952). The Class Struggle in France, 1848 to 1850. Moscow: Progress Publishers.

MARX, Karl (1967). Capital, vol. III. New York: International Publishers.

MARX, Karl (1971). Writings on the Paris Commune. Edited by H. Draper New York: International Publishers.

O’ DONNELL, Guillermo (1973). Modernization and Bureaucratic Authoritarianism: Studies in South American Politics. Berkeley: Institute of International Studies, University of California.

PRZEWORSKI, Adam (1986). Capitalism and Social Democracy. New York: Cambridge University Press. PRZEWORSKI, Adam (2003). "Economic Development and Transitions to Democracy" Ms. Department of Politics. New York University.

PRZEWORSKI, Adam. "Democracy as an Equilibrium” Public Choice (forthcoming). PRZEWORSKI, Adam, and Fernando LIMONGI (1997). "Modernization: Theories and Facts" World Politics 49. PRZEWORSKI, Adam, Michael ALVAREZ, José Antonio CHEIBUB, and Fernando LIMONGI (2000).

Democracy and Development. New York: Cambridge University Press. 